\title{
Investigation of Affinity towards Social Media and Expectations for Success of University Students
}

\author{
Nilay Celik Ercoskun \\ Department of Educational Sciences, Ataturk University, Erzurum, Turkey \\ E-mail: nilay.celik@atauni.edu.tr \\ Ceyhun Ozan (Corresponding author) \\ Department of Educational Sciences, Ataturk University, Erzurum, Turkey \\ E-mail: ozanceyhun@atauni.edu.tr \\ Remzi Y. Kincal \\ Department of Educational Sciences \\ Canakkale Onsekiz Mart University, Canakkale, Turkey \\ E-mail: rkincal@comu.edu.tr
}

Received: July 11, 2019 Accepted: August 21, $2019 \quad$ Published: August 29, 2019

doi:10.5296/jei.v5i2.14703 URL: https://doi.org/10.5296/jei.v5i2.14703

\begin{abstract}
The aim of this study is to investigate university students' affinity towards social media and expectations for success. This research is a descriptive study of general survey. Universe of the study includes first grade students from the faculties of Education, which training teachers, Literature, Science and Theology, where the students receive the pedagogical formation program. Criteria sampling method, one of the purpose sampling methods, was used in the research and 1450 students were included in freshman and senior students studying at these faculties making the sample of the research. It is seen when the study results are considered that university students' affinity in social media differ significantly in terms of gender, faculty, use of social media, and frequency of using social media while there is no significant difference between class grade and general point average. While university students' expectations for success were significantly different according to the variables of gender and general point average; faculty, class grade, use of social media and frequency of using social
\end{abstract}


media did not differ significantly. It was found in the study that there is no significant relationship between university students' affinity towards social media and expectations for success.

Keywords: Affinity towards social media, Expectations for success, University students

\section{Introduction}

Due to the transition from the industrial community to the information society, information sharing has started to be made via the internet worldwide and people have become easy way to reach at any time they want. Accordingly, the use of social media, which is important for the lives of individuals, has become inevitable in both the daily life and the educational process. The most affected ones were children and young people who were born with the existence of technology and social media and who had a different lifestyle than their predecessors.

The use of social media, which has become a part of our daily life, has become more common among children and young people than adults. Since the individuals who were born in the 1980s have found themselves in a world of technological developments, and social media has taken part in their lives (Gallardo-Echenique, Marqués-Molías, Bullen, \& Strijbos, 2015; Kirschner \& Kapinski, 2010). The individuals born in these years are called as "Digital Natives" by Prensky (2001), who consider digital tools as a routine part of their life rather than necessity, have started with technology in the $21^{\text {st }}$ century (Bilgiç, Duman, \& Seferoğlu, 2011). For digital natives, social media are attractive all over the world for easy access to information, communication and social interaction, leisure time, entertainment, virtual expressing of thoughts, sharing information, monitoring other individuals and getting information about them (Whiting \& Williams, 2013). The students are provided with a variety of learning experiences, allowing them to express themselves correctly, to have responsibilities for their own learning and to gain learning experiences without the limit of time and space (Dabbagh \& Kitsantas, 2011; Mather, Douglas, \& O’Brien, 2017; Matzat \& Vrieling, 2016; Mingle \& Adams, 2015). The transfer of learning processes to social media becomes inevitable for digital natives and hence, it can be said that social media has a power to affect the digital natives' perception of learning, school and the future, and thus the success expectations directly.

In the education process defined as the interaction process, the main objective, regardless of the school level, can be expressed as the performance of the students, the creativity of which is expected from them and finally the success of their learning process (Ekici, 2014). Student participation and being effective into the student's own learning process are directly related to their successes in the process (Reyes, Brackett, Rivers, White, \& Salovey, 2012). Functionally, the task of education is to understand why students give up and try to do when they encounter an academic difficulty, and understand how to cope with their own problems, to be responsible for organizing their own learning process, and to solve the difficulties they face with their own efforts (Mega, Ronconi, \& Beni, 2014). Therefore, the success of the learners to experience the sense of success, academic belief and future success expectations and strategies play an important role on the contrary to failing or failing to achieve the 
desired success while decreasing the self-beliefs of prospective success is adversely affected (Nurmi, Aunola, Salmelo-Aro, \& Lindroos, 2003; Tella, 2007; Wigfield, 1994).

Expectations of success are seen as an important part of the expectation-walue theory, which is considered by many theorists and have important perspectives about academic motivation (Wigfield, 1994). Success expectations are related to students 'academic success and learning outcomes, and so they can predict students' perspectives; make predictions about future actions, feelings and thoughts and educational situations, help students to determine the academic skills they can have in the learning-teaching process and affect the relationship between students' self-efficacy perceptions and academic successes (Doménech-Betoret, Abellán-Roselló, \& Gómez-Artiga, 2017). Many factors play a role both in the student's academic success and the success expectations. There are many important factors eg. academic success, teacher training programs and the quality of teachers' performance whether the school has made a difference in student learning (Rivkin, Hanushek, \& Kain, 2005).

Social media is another factor that has a significant impact on student success in the $21 \mathrm{st}$ century. Social media plays an important role in the acquisition of learning experiences both in the outer and inner world of individuals (Hu, Gui, \& Zhang, 2017). Social media has positive and negative effects on learning and success. Social media provides an opportunity for collaborative learning, interactive learning and research, and moreover students can interact with them on their smart phones, using Facebook, Twitter, Instagram, Youtube, Whatsapp and blogs (Mingle \& Adams, 2015). Social media is now seen as a necessary tool for learning and teaching, and it facilitates the integration of formal learning and informal learning as it creates a social learning environment (Chen \& Bryer, 2012). In addition to the positive effects of social media, which are often used effectively by university students, many negative impacts have also been determined. Anderson, Gentile, and Buckley (2007) found out that video play rates were much higher than television viewing rates and had a high risk of having a negative impact on children and adolescents. McLean and Griffiths (2013) also found out that video games took a lot of time and increased the risk of attacking children and adolescents while Levine, Waite, and Bowman (2007) found that students spend a lot of time on messaging, so they spend less time on academic work and they are distracted when performing their academic tasks. Jacobsen and Forste (2011) have stated that university students spend the attention and time they should give to their academic tasks simultaneously by using many social media tools both inside and outside the classroom, and thus it may be difficult to use social media for academic success.

As it results that the rapid increase of information transfer in the information age because of impact of globalization, and the technology is the source of information sharing throughout the world; it has brought along Web 2.0 technology and thus the development of social media. One-way information transfer has become interactive and shared within social media. Thus, people have begun to benefit from various social media platforms where they can create their own Web pages and profiles, know about others, express themselves freely and accurately, share photos and collaborate with their close and distant environments. The use of social media has also become widespread among children and young people, who were born in the 


\section{Macrothink}

1980s, who are regarded as natural users of the Internet and technology and digital natives. Thus, social media has become an important part of the lives and daily activities of children and young people, and thus the use of social media for educational purposes has become inevitable. In education, the use of social media by children and young people how often they are used and how much they have an interest in social media, have brought positive and negative results of social media. While social media has a facilitating effect for learning, sharing, rapid access to information and cooperative work; the use of entertainment, loss of time and distracting effects such as having negative effects can be seen in the classroom and outside the classroom. Due to these effects, it can be said that students 'social media use habits and their interest in social media have an effect on students' academic success and prospective success expectations. However, this study aims to examine the affinity and expectations for success of university students who take the Pedagogical Formation Program, the Faculty of Education, the Faculty of Literature, the Faculty of Science and the Faculty of Theology. For this purpose, the following questions were sought:

(1) Is there a significant difference between university students' social media affinity and their expectations for success in terms of,
a. gender
b. faculty
c. grade level
d. academic average
e. using media
f. frequency of social media usage?

(2) Which purposes do university students use social media?

(3) Is there a significant relationship between university students' affinity in social media and their expectations for success?

\section{Method}

\subsection{Research Design}

Survey model was used in this study which is one of the quantitative research approaches because it is aimed to examine the affinity and expectations for success of university students against social media. The survey method, which has a descriptive structure, allows the identification of the characteristics of the research group, the attitudes, thoughts and ideas about a subject, and the use of many research techniques (Lynn, Erens, \& Sturgis, 2012).

\subsection{Universe and Sample}

The universe of the study consisted of the students of the Kazım Karabekir Faculty of Education, Faculty of Literature, Faculty of Science and Faculty of Theology of Atatürk University in Turkey. Criterion sampling method which is one of the purposive sampling 
methods was used in the study. Therefore, the criteria of the sampling are that freshmen and seniors were selected according their academy educations' effects. Moreover, all students in the Faculty of Education, the Faculty of Literature, the Faculty of Science and the Faculty of Theology and freshmen and seniors students who are subject to the pedagogical formation program were tried to be reached and as a result, the research was conducted with 1424 students and based on volunteerism. 26 incomplete surveys were omitted in data analysis process. The data were implemented by face-to-face, and moreover all the consents forms were obtained from these faculties. Potential respondents of the surveys in the study were 1450 students, and moreover $98 \%$ of the students were returned.

\subsection{Data Collection Tools}

\subsubsection{Social Media Affinity Scale}

The Social Media Affinity Scale is a 5-point Likert-type measurement tool which developed by Gerlich, Browning, and Westermann (2010) to measure the affinity of university students aged 18-40 towards social media. The original form of the scale consists of 13 items and the reliability coefficient of the scale was found to be .77 . The Turkish adaptation of the scale was performed by Çelik-Ercoşkun, Ozan, and Kıncal (2017) and the Cronbach Alpha coefficient was .73. The adapted scale consists of 11 items and three factors explaining 51\% of the total variance: shared interest ( 3 items), importance ( 5 items) and necessity ( 3 items).

\subsubsection{The Generalized Expectancy for Success Scale}

The Generalized Expectancy for Success Scale (GESS), developed by Fibel and Hale (1978) and revised by Hale, Friedler, and Cochran (1992), was developed to measure the general success expectations of university students. The scale is a 5-point Likert-type measurement tool consisting of 25 items with a reliability coefficient of. .92. The Turkish adaptation of the GESS-R was done by Çelik-Ercoşkun, Ozan, and Kıncal (2017) and the Cronbach Alpha coefficient was .87. The adapted GESS-R consists of 21 items and three factors explaining $47 \%$ of the total variance: individual expectation (11 items), social interaction ( 5 items) and failure (5 items).

\subsection{Data Analysis}

In the data analysis, the missing data was first defined and the 26 values were excluded from the data set by performing an extreme value analysis. In order to determine whether the data can be analyzed by parametric tests, it is examined whether the collected data meet the assumptions required for parametric tests. Therefore, it is examined whether the data meet the assumptions of normality, linearity and homogeneity. Levene test was used to determine whether the data obtained from both measuring instruments showed homogeneous distribution. In order to determine whether the data provide the assumption of normality, skewness and kurtosis coefficients were examined. As a result of the analysis, it was seen that parametric tests could be used in data analysis because the data set met the assumptions of normality and homogeneity. SPSS 22.0 program was used in the analysis of data and independent samples t-test, one-way analysis of variance (ANOVA), and moreover correlation analysis was used. In addition to the sub-dimensions as well as the total scores, 
the necessary analyzes were made on the adapted scales.

\section{Findings}

Table 1 presents the statistical information regarding the differences of university students' affinity towards social media and their generalized expectations for success according to gender variable.

Table 1. Affinity towards social media and generalized expectations for success by gender variable

\begin{tabular}{|l|l|l|l|l|l|l|}
\hline & Gender & $\mathrm{n}$ & $\overline{\mathrm{X}}$ & $\mathrm{df}$ & $\mathrm{t}$ & $\mathrm{p}$ \\
\hline \multirow{3}{*}{ Affinity towards Social Media } & Female & 958 & 3.1091 & .5340 & \multirow{2}{*}{2.269} & \multirow{2}{*}{$.023^{*}$} \\
\cline { 2 - 8 } & Male & 450 & 3.1797 & .5661 & & \\
\hline \multirow{2}{*}{ Generalized Expectations for Success } & Female & 958 & 3.8283 & .4334 & \multirow{2}{*}{2.551} & \multirow{2}{*}{$.011^{*}$} \\
\cline { 2 - 6 } & Male & 450 & 3.7641 & .45612 & & \\
\hline
\end{tabular}

Note. ${ }^{*} \mathrm{p}<.05$.

According to Table 1, it is seen that there is a significant difference in favor of men in the affinty towards social media scale according to gender variable $(\mathrm{t}=2.269 ; \mathrm{p}<.05)$, while there is a significant difference on behalf of women in the generalized expectations for success scale $(t=2.551 ; \mathrm{p}<.05)$. The mean and standard deviation values of the university students according to the faculty variable according to the scale of the affinity toward social media scale and generalized expectations for success are given in Table 2.

Table 2. Affinity towards social media and generalized expectations for success by faculty variable

\begin{tabular}{|l|l|l|l|l|l|l|}
\hline & \multicolumn{3}{|c|}{ Affinity towards Social Media } & \multicolumn{3}{c|}{ Generalized Expectations for Success } \\
\hline Faculty & $\mathrm{n}$ & $\overline{\mathrm{X}}$ & $\mathrm{Sd}$ & $\mathrm{n}$ & $\overline{\mathrm{X}}$ & $\mathrm{Sd}$ \\
\hline Education & 368 & 3.24 & .56 & 368 & 3.80 & .47 \\
\hline Literature & 698 & 3.12 & .53 & 698 & 3.82 & .44 \\
\hline Science & 92 & 3.15 & .57 & 92 & 3.80 & .52 \\
\hline Theology & 266 & 3.01 & .55 & 266 & 3.80 & .38 \\
\hline
\end{tabular}

Table 2 shows that the mean values of the scores obtained from the affinity towards social media scale are 3.24 for the students studying in the Faculty of Education, 3.12 for the students in the Faculty of Literature, 3.15 for the students in the Faculty of Science. Moreover, it is seen that there is 3.01 for the students studying in the Faculty of Theology. The mean 


\section{Al Macrothink}

values of the scores obtained from the affinity towards social media scale are 3.80 for the students studying in the Faculty of Education, 3.82 for the students in the Faculty of Literature, 3.80 for the students in the Faculty of Science and It is seen that there is 3.80 for the students studying in the Faculty of Theology. Table 3 presents the statistical information regarding the differences of university students' affinity towards social media and their generalized expectations for success according to faculty variable.

Table 3. ANOVA results by faculty variable

\begin{tabular}{|l|l|l|l|l|l|l|}
\hline & Source & Sum of Squares & df & Mean Squares & F & p \\
\hline \multirow{4}{*}{ Affinity towards Social Media } & Between Groups & 8.117 & 3 & 2.706 & & \\
\cline { 2 - 5 } & Within Groups & 416.971 & 1420 & .294 & \multirow{3}{*}{9.214} & $.000^{*}$ \\
\cline { 2 - 5 } & Total & 425.088 & 1423 & & & \\
\hline \multirow{3}{*}{$\begin{array}{l}\text { Generalized Expectations } \\
\text { for Success }\end{array}$} & Between Groups & .149 & 3 & .050 & & \\
\cline { 2 - 5 } & Within Groups & 276.140 & 1420 & .194 & .857 \\
\cline { 2 - 5 } & Total & 276.289 & 1423 & & & \\
\hline
\end{tabular}

Note. ${ }^{*} \mathrm{p}<.05$.

According to Table 3, it is seen that the scores of university students on the affinity social media scale have varied significantly in terms of faculty variable $(F=9.124 ; p<.05)$. The Tukey test was conducted from Post Hoc tests in order to see which group was among these differences. As a result of the Tukey test, it shows in favor of the Faculty of Education according to the scores of the faculty variable obtained from the social media interest scale, between the Faculty of Education and the Faculty of Literature while it shows in favor of the Faculty of Education between the Faculty of Education and the Faculty of Theology. There is a significant difference between the Faculty of Literature and the Faculty of Theology on behalf of the Faculty of Literature. It is observed that the scores of the university students on the generalized expectations for success scale do not differ according to the faculty variables. $(\mathrm{F}=.256 ; \mathrm{p}>.05)$. Table 7 presents the statistical information regarding the differences of university students' affinity towards social media and generalized expectations for success in terms of academic year variable. 
Table 4. Independent groups t-test results by grade level variable

\begin{tabular}{|l|l|l|l|l|l|l|}
\hline & Academic year & $\mathrm{n}$ & $\overline{\mathrm{X}}$ & $\mathrm{Sd}$ & $\mathrm{t}$ & $\mathrm{p}$ \\
\hline \multirow{2}{*}{ Affinity towards Social Media } & Freshmen & 589 & 3.15 & .57 & \multirow{2}{*}{.854} & \multirow{2}{*}{.393} \\
\cline { 2 - 8 } & Seniors & 835 & 3.12 & .53 & & \\
\hline \multirow{2}{*}{ Generalized Expectations for Success } & Freshmen & 589 & 3.79 & .43 & \multirow{2}{*}{1.155} & \multirow{2}{*}{.248} \\
\cline { 2 - 6 } & Seniors & 835 & 3.82 & .44 & & \\
\hline
\end{tabular}

Note. $* \mathrm{p}<.05$.

Table 4 shows that there is no significant difference between the affinity towards social media $(\mathrm{t}=.854 ; \mathrm{p}>.05)$ and generalized expectations for success $(\mathrm{t}=1.155 ; \mathrm{p}>.05)$ in terms of academic year variable. Table 5 presents the statistical information about the differences of the different faculty students' affinity towards social media and generalized expectations for success according to the academic year variable.

Table 5. Affinity towards social media and generalized expectations for success in different faculties in terms of grade level variable

\begin{tabular}{|c|c|c|c|c|c|c|c|}
\hline & Faculty & Academic years & $\mathrm{n}$ & $\overline{\mathrm{X}}$ & $\mathrm{Sd}$ & $\mathrm{t}$ & $\mathrm{p}$ \\
\hline \multirow{8}{*}{$\begin{array}{l}\text { Affinity towards } \\
\text { Social Media }\end{array}$} & \multirow{2}{*}{ Faculty of Education } & Freshmen & 186 & 3.28 & .57 & \multirow{2}{*}{1.416} & \multirow{2}{*}{.158} \\
\hline & & Seniors & 182 & 3.20 & 55 & & \\
\hline & \multirow{2}{*}{ Faculty of Literature } & Freshmen & 272 & 3.16 & .54 & \multirow{2}{*}{1.430} & \multirow{2}{*}{.153} \\
\hline & & Seniors & 426 & 3.10 & .52 & & \\
\hline & \multirow{2}{*}{ Faculty of Science } & Freshmen & 45 & 3.11 & .52 & \multirow{2}{*}{.736} & \multirow{2}{*}{463} \\
\hline & & Seniors & 47 & 3.19 & .61 & & \\
\hline & \multirow{2}{*}{ Faculty of Theology } & Freshmen & 86 & 2.86 & .56 & \multirow[b]{2}{*}{3.228} & \multirow[b]{2}{*}{$.001 *$} \\
\hline & & Seniors & 180 & 3.08 & .53 & & \\
\hline \multirow{8}{*}{$\begin{array}{l}\text { Generalized Expectations } \\
\text { for Success }\end{array}$} & \multirow{2}{*}{ Faculty of Education } & Freshmen & 186 & 3.80 & .45 & \multirow[b]{2}{*}{.221} & \multirow[b]{2}{*}{.825} \\
\hline & & Seniors & 182 & 3.79 & .48 & & \\
\hline & \multirow{2}{*}{ Faculty of Literature } & Freshmen & 272 & 3.80 & .43 & \multirow{2}{*}{995} & \multirow{2}{*}{.320} \\
\hline & & Seniors & 426 & 3.83 & .44 & & \\
\hline & \multirow{2}{*}{ Faculty of Science } & Freshmen & 45 & 3.73 & .51 & \multirow{2}{*}{1.260} & \multirow{2}{*}{.211} \\
\hline & & Seniors & 47 & 3.87 & .53 & & \\
\hline & \multirow{2}{*}{ Faculty of Theology } & Freshmen & 86 & 3.78 & .35 & \multirow{2}{*}{.494} & \multirow{2}{*}{622} \\
\hline & & Seniors & 180 & 3.80 & .39 & & \\
\hline
\end{tabular}

Note. ${ }^{*} \mathrm{p}<.05$. 


\section{MIN Macrothink}

According to Table 5, according to the academic year of the scores obtained from the affinity towards social media scale, there was not any significant difference among the Faculty of Education $(\mathrm{t}=1.416 ; \mathrm{p}>.05)$, Faculty of Literature $(\mathrm{t}=1.430 ; \mathrm{p}>.05)$ and Faculty of Science $(t=.736 ; p>.05)$, but moreover for the Faculty of Theology, there was a significant difference in favor of seniors $(t=3.228 ; \mathrm{p}<.05)$. The scores of the general expectations for success scale did not differ significantly in terms of academic years of the Faculty of Education, Faculty of Literature, Faculty of Science and Faculty of Theology. The mean and standard deviation values of the university students according to the cumulative average score variable according to the scale of the affinity toward social media scalle and generalized expectations for success are given in Table 6.

Table 6. Affinity towards social media and generalized expectations for success by cumulative average score variable

\begin{tabular}{|c|c|c|c|c|c|c|}
\hline \multirow{2}{*}{ Cumulative average scores } & \multicolumn{3}{|c|}{ Affinity towards Social Media } & \multicolumn{3}{|c|}{ Generalized Expectations for Success } \\
\hline & $\mathrm{n}$ & $\overline{\mathrm{X}}$ & $\mathrm{Sd}$ & $\mathrm{n}$ & $\overline{\mathrm{X}}$ & $\mathrm{Sd}$ \\
\hline $0-2.00$ & 167 & 3.21 & .55 & 167 & 3.72 & .47 \\
\hline $2.01-2.50$ & 342 & 3.16 & .51 & 342 & 3.77 & .43 \\
\hline $2.51-3.00$ & 447 & 3.10 & .56 & 447 & 3.82 & .44 \\
\hline $3.01-4.00$ & 407 & 3.12 & .55 & 407 & 3.87 & .44 \\
\hline
\end{tabular}

Table 6 shows that the mean value of the scores on the affinity towards social media scale is 3.21 for the students whose cumulative average scores are between $0-2.00$; the mean 3,16 for students between 2.01-2.50; the mean 3.10 for students between 2.51-3.00. However, it is seen that the mean value 3.12 for the students are between 3.01-4.00. When the average values of the scores of the general expectations for success scale are examined, average of grade point averages for students between $0-2.00$ is $3.72 ; 3.77$ for students between 2.01-2.50; 3.82 for students between 2.51-3.00. Moreover, it is seen that it is 3.87 for the students between 3.01-4.00. Table 7 presents the statistical information about the differences of university students' affinity towards social media and their generalized expectations for success in terms of grade point averages. 
Table 7. ANOVA results by cumulative average score variable

\begin{tabular}{|c|c|c|c|c|c|c|}
\hline & Source & Sum of Squares & df & Mean Squares & $\mathrm{F}$ & $\mathrm{p}$ \\
\hline \multirow{3}{*}{ Affinity towards Social Media } & Between Groups & 1.674 & 3 & .558 & \multirow{3}{*}{1.878} & \multirow{3}{*}{.131} \\
\hline & Within Groups & 403.913 & 1359 & .297 & & \\
\hline & Total & 405.587 & 1362 & & & \\
\hline \multirow{3}{*}{$\begin{array}{l}\text { Generalized Expectations } \\
\text { for Success }\end{array}$} & Between Groups & 3.187 & 3 & 1.062 & \multirow{3}{*}{5.469} & \multirow{3}{*}{$.001 *$} \\
\hline & Within Groups & 273.979 & 1359 & .194 & & \\
\hline & Total & 267.165 & 1362 & & & \\
\hline
\end{tabular}

Note. ${ }^{*} \mathrm{p}<.05$.

According to Table 7, it is observed that the scores of university students on the affinity towards social media scale have not differed significantly according to cumulative average score $(\mathrm{F}=1.878 ; \mathrm{p}>.05)$; The scores of the general expectations for success scale differed significantly in terms of the cumulative average score $(p<.05)(f=5.469 ; p<.05)$. The Tukey test was conducted from Post Hoc tests in order to see which group was among these differences. According to the results of Tukey test, the average of the scores of the generalized expectations for success scale was 3.01-4.00 with the average of the cumulative grade point average and between 0-2.00 between 3.01-4.00 in favor of the students; between 3.01-4.00 and 2.01-3.00, there are significant differences in favor of students with 3.01-4.00. Table 8 presents the statistical information on the differences of the different faculty students' affinity towards social media and generalized expectations for success in terms of the social media usage.

Table 8. Independent groups t-test results by social media usage variable

\begin{tabular}{|l|l|l|l|l|l|l|}
\hline & Social Media Usage & $\mathrm{n}$ & $\overline{\mathrm{X}}$ & $\mathrm{Sd}$ & $\mathrm{t}$ & $\mathrm{p}$ \\
\hline \multirow{2}{*}{ Affinity towards Social Media } & Yes & 1356 & 3.15 & .53 & \multirow{2}{*}{5.774} & \multirow{2}{*}{$.000^{*}$} \\
\cline { 2 - 8 } & No & 64 & 2.75 & .58 & & \\
\hline \multirow{2}{*}{$\begin{array}{l}\text { Generalized Expectations } \\
\text { for Success }\end{array}$} & Yes & 1356 & 3.81 & .44 & \multirow{2}{*}{.758} & .449 \\
\cline { 2 - 6 } & No & 64 & 3.74 & .43 & & \\
\hline
\end{tabular}

Note. ${ }^{*} \mathrm{p}<.05$.

According to Table 8, it is seen that the scores of the affinity towards social media scale differed significantly in favor of social media users according to the variable of social media $(\mathrm{t}=5.774 ; \mathrm{p}<.05)$; It is observed that the scores of the generalized expectations for success scale did not vary significantly $(\mathrm{t}=.758 ; \mathrm{p}>.05)$. The mean and standard deviation values of the university students in terms of the frequency of social media usage variable are given in 
Table 9 according to the scale of the affinity toward social media scale and generalized expectations for success.

Tablo 9. Affinity towards social media and generalized expectations for success by frequency of social media usage variable

\begin{tabular}{|l|l|l|l|l|l|l|}
\hline & \multicolumn{3}{|c|}{ Affinity towards Social Media } & \multicolumn{3}{l|}{ Generalized Expectations for Success } \\
\hline Frequency of Usage & $\mathrm{n}$ & $\overline{\mathrm{X}}$ & $\mathrm{Sd}$ & $\mathrm{n}$ & $\overline{\mathrm{X}}$ & $\mathrm{Sd}$ \\
\hline Every day more than once & 1038 & 3.22 & .51 & 1038 & 3.80 & .44 \\
\hline Once per day & 61 & 2.94 & .53 & 61 & 3.77 & .48 \\
\hline More than once a week & 184 & 3.03 & .52 & 184 & 3.83 & .42 \\
\hline Once a week & 27 & 3.00 & .67 & 27 & 3.81 & .51 \\
\hline Several times a month & 54 & 2.71 & .59 & 54 & 3.84 & .50 \\
\hline Never & 45 & 2.59 & .55 & 45 & 3.84 & .44 \\
\hline
\end{tabular}

According to Table 9, the mean values of affinity towards social media scores are 3.2190 for the students whose social media usage frequency is more than once every day; 2.9391 for students once per day; 3.0337 for students with more than once a week; for students who have once a week, 2.9968; 2.7063 for students several times a month. However, it is seen that for students who have never had 2.5917. When the mean values of the scores of the generalized expectations for success scale are examined, the frequency of social media usage is 3.8048 for the students whose frequency is more than once every day; 3.7667 for students once per day; 3.8256 for students with more than once a week; for students who are once a week, $3.8109 ; 3.8352$ for students several times a month; for students who have never been seen, it is 3.8357 . Table 10 presents the statistical information regarding the differences of university students' affinity towards social media and their generalized expectations for success in terms of frequency of social media usage.

Table 10. ANOVA results by frequency of social media usage variable

\begin{tabular}{|l|l|l|l|l|l|l|}
\hline & Source & Sum of Squares & df & Mean Squares & F & $\mathrm{p}$ \\
\hline \multirow{3}{*}{$\begin{array}{l}\text { Affinity towards } \\
\text { Social Media }\end{array}$} & Between Groups & 36.091 & 3 & 7.218 & & \\
\cline { 2 - 6 } & Within Groups & 384.017 & 1403 & .274 & \multirow{3}{*}{26.372} & $.000^{*}$ \\
\cline { 2 - 6 } & Total & 420.108 & 1408 & & & \\
\hline \multirow{3}{*}{$\begin{array}{l}\text { Generalized Expectations } \\
\text { for Success }\end{array}$} & Between Groups & .246 & 3 & .049 & & \\
\cline { 2 - 6 } & Within Groups & 272.065 & 1403 & .194 & .254 & .938 \\
\cline { 2 - 6 } & Total & 272.311 & 1408 & & & \\
\hline
\end{tabular}

Note. $* \mathrm{p}<.05$. 


\section{MInstitute ${ }^{\text {Macrothink }}$}

Table 10 shows that the scores of university students on the affinity towards social media scale vary significantly according to frequency of social media usage $(F=26.372 ; p<.05)$. The Tukey test was conducted from Post Hoc tests in order to see which group was among these differences. The results of Tukey test show that there are differences among students in favor of using social media more than once every day a month and also, it is in favor of students who use social media more than once per day. Another result is that the students who use it on eper day are in favor of the students who never use them more than once per day. The Tukey test's another result is in favor of students who use more than once a week compared to the students who never use then once per day. There is a significant difference in favor of the students who use once a week compared to students who never use it once a week. The scores of the generalized expectations for success scale did not vary significantly according to the frequency of social media usage $(\mathrm{F}=.254 ; \mathrm{p}>.05)$. University students were asked to rank the social media for their intended use and statistical information about the purposes of using social media was given in Table 11.

Table 11. Purpose of using social media for university students

\begin{tabular}{|l|l|l|l|}
\hline & 1. Order of importance & 2. Order of importance & 3. Order of importance \\
\hline Purpose of Using & $\mathrm{f}(\%)$ & $\mathrm{f}(\%)$ & $\mathrm{f}(\%)$ \\
\hline 1. Getting information & $399(\% 28)$ & $145(\% 10.2)$ & $126(\% 8.8)$ \\
\hline 2. Track events & $291(\% 20.4)$ & $239(\% 16.8)$ & $113(\% 7.9)$ \\
\hline 3. Receiving news & $104(\% 7.3)$ & $198(\% 13.9)$ & $238(\% 16.7)$ \\
\hline 4. Getting to know people better & $15(\% 1.1)$ & $43(\% 3)$ & $35(\% 2.5)$ \\
\hline 5. Exchange of ideas & $7(\% 0.5)$ & $42(\% 2.9)$ & $60(\% 4.2)$ \\
\hline 6. Video sharing & $2(\% 0.2)$ & $15(\% 1.1)$ & $30(\% 2.1)$ \\
\hline 7. Getting new friends & $5(\% 0.4)$ & $6(\% 0.4)$ & $15(\% 1.1)$ \\
\hline 8. Having fun and relaxation & $149(\% 10.5)$ & $102(\% 7.2)$ & $89(\% 6.3)$ \\
\hline 9. Communicating with friends & $121(\% 8.5)$ & $89(6.3)$ & $102(\% 7.2)$ \\
\hline 10. Leisure time & $63(\% 4.4)$ & $50(\% 3.5)$ & $63(\% 4.4)$ \\
\hline 11. Share photos & $17(\% 1.2)$ & $43(\% 3)$ & $52(\% 3.7)$ \\
\hline & & &
\end{tabular}

According to Table 11, it is seen that university students' purpose of using social media is to get information $(399,28 \%)$, to track events $(239,16.8 \%)$ and to receive news $(238,16.7 \%)$. Table 12 shows the relationships between university students' scores on the affinity towards social media scale and generalized expectations for success scale. 


\section{$\Lambda$ Macrothink}

Table 12. Relationship between the affinity towards social media and the generalized expectations for success scale

\begin{tabular}{|l|l|l|}
\hline & $\begin{array}{l}\text { Affinity towards social } \\
\text { media scale }\end{array}$ & $\begin{array}{l}\text { Generalized expectations } \\
\text { for success scale }\end{array}$ \\
\hline Affinity towards social media scale & 1 & $.038^{*}$ \\
\hline Generalized expectations for success scale & & 1 \\
\hline
\end{tabular}

Note. ${ }^{*} \mathrm{p}<.01$.

Table 12 shows that there is no significant relationship between the scores of the university students' affinity towards social media scale and the generalized expectations for success scale.

\section{Conclusion and Discussion}

The results of the study show that the affinity of male students towards social media was higher than female students. This situation can be explained by the fact that male students use social media more than female students. Similar to these results, Baran and Ata (2013), Özsarı and Batdal Karaduman (2016) reported that male students used social media more than female students in studies conducted with university students. It is seen that social media is more used by men in the younger people in the studies conducted to determine the demographic characteristics of social media users in the United States, and moreover it is parallel to the findings of the research (Duggan \& Brenner, 2013; Lenhart, Purcell, Smith, \& Zickuhr, 2010). According to Lenhart (2015) report, it is stated that men use social media more than women, and moreover women use social networking sites such as Facebook, Instagram, Snapchat, Pinterest and Tumblr while men use more social games. According to the results, it can be said that men have a more positive approach to internet and social media use. Broos (2005) found that men had a more positive attitude towards technology and internet than women; Wasserman and Richmond-Abbott (2005) emphasized that men used internet skills better than women. Ozan and Taşgın (2017) also found that self-efficacy perceptions of male prospective teachers were significantly higher than the female prospective teachers in terms of technological processes and conceptual knowledge of educational technology standards. According to Ozan's another study (2009) conducted with teachers, it was found that male classroom teachers' self-efficacy perceptions about computer technologies were significantly higher than female teachers. On the other hand, Gündoğdu, Silman, and Ozan (2011) did not reach a significant difference between teachers' opinions about computer use.

It is seen that the general expectations for success of female students are higher than male students in contrast to the results related to affinity towards social media in the study. The positive and motivating effect of success expectations on students' learning and learning outcomes has been shown in recent years (Cotton, 1989; Haesler, 2012). Reese and Dietrich (2014) stated that individuals with a high expectation of success were more motivated and behaved more intentionally towards how they would behave. Krämer, Karacora, Lucas, 
Dehghani, Rüther, and Gratch (2016) have stated that the expectation for success is determined by personal beliefs that competencies are necessary and available to achieve a job. Bigman, Mauss, Gross, and Tamir (2016) emphasized that high expectations for success kept individuals' feelings and attitudes away from negative thinking. Similarly, Eccles (2009) stated that the expectation for success with a psychological effect was an effective source of motivation for the future success and choices of the individual, and he emphasized that it improved the sense of confidence in using the competencies required for the sense of success. It can be said that the expectation for success mutually affects each other by beliefs, attitudes, competence perception and motivation according to related literature. Therefore, it can be said that the beliefs of women about achieving men are stronger and their motivation is better for the research.

The study results about the affinity social media in terms of faculty, it is seen that the scores of the affinity towards social media scale differ significantly among the other faculties except the faculty of science. The research results of the students in the faculty of education are higher than the students' results in the faculty of literature and faculty of theology. Students studying at the faculty of education take courses such as instructional technologies and material design within the scope of their teacher training programs, and they consider the use of technology and social media in organizing the educational environment and learning process and encourage students to use them. Additionally, the fact that the teaching programs the prospective teachers should use in their professional life draw attention to the use of technology as one of the basic skills of 21 st century, and also it is expected to have these skills of prospective teachers and teachers to use technology and social media skills. It can be said that the students of the faculty of education are more interested in social media than the students in other faculties and they can perceive social media as a useful tool in the learning-teaching process. According to study by Sarsar, Başbay, and Başbay (2015), it was found that the learning environment organized by using social media met the expectations of the course, so the students contributed to enjoy the lesson and motivated against learning and the use of social media was found to be efficient and necessary by the students. Similarly, Öztürk and Akgün (2012), in a study carried out within the faculty of edlucation, found that social media is a good way to use social media throughout learning process, as well as opportunities for social media to enrich and share resources; opinions were obtained. Chen and Bryer (2012) found that social media and communication technologies had an important potential to create a learning environment between students and teachers, and that social media is an effective tool for formal and informal learning. Kelly, Thompson, Green, and Vice (2017) stated that teacher training programs required the support of social media both in teacher education and professional development.

When the results of general expectations for success are examined, it is seen that there is no significant difference among the faculties. In parallel with this result, it was observed that university students' interest in social media and their overall success expectations did not differ significantly according to the academic year variable without distinction of faculty. When the grade level variable was taken together with the faculty variable, it was found that the students of faculty of theology only changed their affinity towards social media in a 
significant way in favor of seniors in terms of academic years. Similarly, it is seen that the general expectations for success of the students do not differ significantly according to the grade level variable for any faculty. It is expected that the received university education will be in the direction that will increase the success expectations of the students. According to the results of the study, it can be said that the education of university students does not contribute to the social media usage in a significant way that affects the interest and general expectations for success. However, it can be said that the university education and pedagogical formation program of the students did not have a significant effect on students' affinity towards social media and their general expectations for success.

The study shows that the affinity of university students towards social media did not differ significantly according to cumulative grade point average variable. Therefore, it can be said that the cumulative grade point average has no effect upon social media. On the other hand, it is seen that the general expectations for success of university students differ significantly according to the cumulative grade point average and the general expectations for success of students with a high cumulative grade point average are high. According to this result, it is observed that the students with high cumulative grade point average have higher beliefs and motivations about success, and they feel more adequate to achieve a job, and thus, it increases their general expectations for success. It is also possible to comment on the academic success of the students who have high general expectations for success and hence their cumulative grade point average increases. Nurmi, Aunola, Salmela-Aro, and Lindroos (2003) study's results are similar to the results obtained from the study, and moreover they concluded that the success expectations of the students were a strong predictor of their academic success and that their academic success was related to the motivation and satisfaction level of the students. and fear of failing to avoid taking responsibility and low academic success. Wentzel and Wigfield (1998) found that the expectation of success had an impact on academic performance by influencing the individual's belief in what $\mathrm{s}$ /he could do. DeBerart, Spielmans, and Julka (2004) found that the expectation for success was a psychological factor predicting academic success while De Castella, Byrne, and Covington (2013) stated that the expectation for success affects the future performance of individuals.

According to the research findings related to social media according to frequency of using social media, it is seen that students who use social media frequently have higher affinity towards social media. It was concluded that general expectations for success of university students did not vary significantly according to the frequency of social media usage. According to the findings of the research, it is found out that university students mostly use social media for getting information, tracking events, recieving news, getting to know people better, transferring ideas, sharing videos, getting new friends, having fun and relaxing, communicating with friends, doing leisure time activities and sharing photos. Similarly, Solmaz, Tekin, Herzem, and Demir (2013) reported that social media is frequently used for communicating with friends, having fun, relaxing and doing leisure time activities, messaging, following the agenda, and reaching information. Zhan, Sung, Wang, and Zhang (2016) stated that social media was used for social interaction, communication with friends and this had a positive effect on individuals. Another study to determine the demographic characteristics of 
social media users in the United States (Lenhart, Purcell, Smith, \& Zickuhr, 2010) says that social media is often used for communicating with friends, sharing on friends' pages, messaging, sharing photos, videos, and status. It is seen that others use their postings for comments. Villanti, Johnson, Ilakkuvan, Jacobs, Graham, and Rath (2017) stated that the majority of young people used social media, and moreover their personal goals were decisive in using social media sites. For example, the less educated young people are more active in social networking sites such as Linkedin in order to look for a job while social networking sites such as Snapchat are preferred for sharing photos and videos with their friends, and the use of social networking sites such as ethnicity, education, gender and socio-economic status they differed. Social media sites such as Facebook were used more intensively in a study which social media usage frequency and social media usage were evaluated together. According to social media usage frequency, video and photo sharing, collaboration, discussion forums, idea generation, music sharing, they are more active in the virtual world where they are more active in the blogs and work-related social networking sites. Therefore, it was concluded that they used social media more actively to communicate with friends, to share homework in university, to learn online, to share information, to spend leisure time, to have fun, to communicate with family members, to share ideas and to make advertisements (Paliszkiewicz, Mądra, Filipiak, Svanadze, \& Jikia, 2017).

It is noteworthy that there is no significant relationship between university students' affinity towards social media and their relationship with general expectations for success. It is observed that university students' affinity towards social media is not significantly different according to the cumulative grade point average similar to the findings of the study. Thus, it can be said that university students have not used social media with the aim of being successful, and moreover their success expectations have not had a significant effect on social media interest.

Meanwhile the lack of a relationship between affinity towards social media and expectations for success can be explained by both students' and instructors' perspectives on social media and the possibility that social media cannot be used actively in the education process. In contrast to the results of using of social media as a tool to increase the success expectations of the social media in the 21 st century, social media became an integral part of life, and therefore it is effective on the factors that may be affected by the success expectations such as academic success, motivation and learning. Moreover it could be considered as a positive result of social media.

Similarly, social media can only be used for spending leisure time, messaging, communicating with friends via social networking sites, sharing photos, videos and music, using video games. But it could not contribute to the learning process for especially young people because of the expectations of individuals, and it may be among the negative consequences expected to have an impact on their professional life. Legaree's study (2015) says that many social networking sites such as Facebook and Twitter were used both in school and outside the school for both learning and teaching purposes by students and faculty members at universities. 


\section{Macrothink}

Moreover, they have used to increase the interaction and communication among the social media and the students and the instructors. They have also used social media to increase the cooperation among the students, to reach the necessary resources, to provide the students with the learning materials they can use after the class, to provide an alternative platform to support the official educational institutions, and also to provide the students with the skills needed to be successful in their professional life. Al-Rahmi and Othman (2013) stated that social media could be an important potential for student-student interaction, student-teacher interaction, cooperative learning and academic performance of students. The study, conducted by Krutka, Nowell, and Whitlock (2017) to see the impact of social media on prospective teachers, concluded that there was a trend towards social media pedagogy, which the social media had a positive effect on relations, provided convenience and a compelling perspective for the future. Similar to the results of the study, Alwagait, Shahzad, and Alim (2014) concluded that there was no significant relationship between social media usage and academic achievement, in addition to the fact that the use of social media adversely affects students especially in terms of time management. Social media usage should be planned in a balanced way in order to increase their academic performance. Ravizza, Hambrick, and Fenn (2014) reported that social media adversely affected the learning environment and academic success when it was not used for academic purposes. Moreover, Lau (2017) stated that various social media tools used by university students in their daily lives had a negative impact upon the relationship between students and teachers, and also these negative effects are such as creating cyber bullying and a negative relationship between academic achievement and non-academic social media use.

In conclusion, it is observed that social media affects academic success and success expectations according to the purpose of use while the use of social media for academic purposes has positive effects such as cooperation among peers on success, increasing student-student interaction, easy access to information, providing material for learning environment. Another result is that the use of social media for non-academic purposes has no impact on success, and therefore, it has no negative effect on the success expectations of students, such as time not being well managed, time wasting and distraction. According to the common impact of social media today, the frequent use of social media, especially by young people, can be transformed into an important potential for learning and teaching in higher education. Therefore, it is possible to provide education on media literacy in order to be able to use social media for students and academic staff in higher education and to support the education programs with social media usage.

\section{Acknowledgements}

This study held in Antalya, Turkey on 18 April to 22 April 2018 were presented as oral presentations at the $27^{\text {th }}$ International Conference on Educational Sciences.

\section{References}

Almedia, F. (2012). Web 2.0 technologies and social networking security fears in enterprises. International Journal of Advanced Computer Science and Applications, 3(2), 152-156. https://doi.org/10.14569/IJACSA.2012.030226 


\section{Macrothink}

Al-Rahmi, W., \& Othman, M. (2013). The impact of social media use on academic performance among university students: A pilot study. Journal of Information Systems Research and Innovation, 4(12), 1-10.

Alwagait, E., Shahzad, B., \& Alim, S. (2015). Impact of social media usage on students academic performance in Saudi Arabia. Computers in Human Behavior, 51, 1092-1097. https://doi.org/10.1016/j.chb.2014.09.028

Anderson, C. A., Gentile, D. A., \& Buckley, K. E. (2007). Violent video game effects on children and adolescents: Theory, Research, and Public Policy. New York: Oxford University Press. https://doi.org/10.1093/acprof:oso/9780195309836.001.0001

Baran, B., \& Ata, F. (2013). University students' web 2.0 technologies usage, skill levels and educational usage. Education and Science, 38(169), 192-208.

Bigman, Y. E., Mauss, I. B., Gross, J. J., \& Tamir, M. (2016). Yes I can: Expected success promotes actual success in emotion regulation. Cognition and Emotion, 30(7), 1380-1387. https://doi.org/10.1080/02699931.2015.1067188

Bilgiç, H. G., Duman, D., \& Seferoğlu, S. S. (2011). The characteristics of digital natives' and their effects on the design of online environments. XIII. Akademik Bilişim Konferans1, Malatya, Turkey.

Boyd, D. M., \& Ellison, N. B. (2007). Social network sites: Definition, history, and scholarship. Journal of Computer Mediated Communication, 13(1), 210-230. https://doi.org/ 10.1111/j.1083-6101.2007.00393.x

Broos, A. (2005). Gender and information and communication technologies (ICT) anxiety: Male self-sssurance and female hesitation. Cyberpsychology \& Behavior, 8(1), 21-31. https://doi.org/10.1089/cpb.2005.8.21

Brown, T. A. (2006). Confirmatory factor analysis for applied research. New York, NY: Guilford.

Çelik-Ercoşkun N., Ozan C., \& Kıncal R. Y. (2017). Genel Başarı Beklentileri Ölçeği’nin Türkçe'ye uyarlanması: Geçerlik ve güvenirlik çalışması. 5 Uluslararası Eğitim Programları ve Öğretim Kongresi’nde sunulan bildiri, Muğla, Turkey.

Çelik-Ercoşkun N., Ozan C., \& Kıncal R. Y. (2017). Sosyal Medya İlgi Ölçeği’nin Türkçe’ye uyarlanması: Geçerlik ve güvenirlik çalışması. 5 Uluslararası Eğitim Programları ve Öğretim Kongresi'nde sunulan bildiri, Muğla, Turkey.

Chen, B., \& Bryer, T. (2012). Investigating instructional strategies for using social media in formal and informal learning. The International Review of Research in Open and Distributed Learning, 13(1), Retrieved September 14, 2017, from http://www.irrodl.org/index.php/irrodl/ article/view/1027/2073?utm_campaign $\% 20=$ elearningindustry.com\&utm_source=/10-tips-toeffectively-use-social-media-in-formal-learning\&utm_medium=link

Çokluk, Ö., Şekercioğlu, G., \& Büyüköztürk, Ş.(2012). Sosyal bilimler için çok değişkenli 


\section{MlMacrothink}

SPSS ve LISREL uygulamaları. Ankara: Pegem Akademi Yayıncılık.

Cormode, G., \& Krishnamurthy, B. (2008). Key differences between Web 1.0 and Web 2.0. First Monday Peer-Reviewed Journal on the Internet, 13(6), 1-10. https://doi.org/10.5210/ fm.v13i6.2125

Cotton, K. (1989). Expectations and student outcomes. Retrieved September 12, 2017, from http://educationnorthwest.org/sites/default/files/ExpectationsandStudentOutcomes.pdf

Dabbagh, N., \& Kitsantas, A. (2011). Personal Learning Environments, social media, and self-regulated learning: A natural formula for connecting formal and informal learning. Internet and Higher Education, 15, 3-8. https://doi.org/10.1016/j.iheduc.2011.06.002

De Castella, K., Byrne, D., \& Covington, M. (2013). Unmotivated or motivated to fail? A cross-cultural study of achievement motivation, fear of failure, and student disengagement. Journal of Educational Psychology, 105(3), 861-926. https://doi.org/10.1037/a0032464

DeBerard, M. S., Spielmans, G., \& Julka, D. (2004). Predictors of academic achievement and retention among college freshmen: A longitudinal study. College Student Journal, 38(1), $66-80$.

Doménech-Betoret, F., Abellán-Roselló, L., \& Gómez-Artiga, A. (2017). Self-efficacy, satisfaction, and academic achievement: The mediator role of students' expectancy-value beliefs. Frontiers in Psychology, 8, 1-12. https://doi.org/10.3389/fpsyg.2017.01193

Duggan, M., \& Brenner, J. (2013). The demographics of social media users-2012. Washington: Pew Internet \& American Life Project.

Eccles, J. S. (2009). Who am I and what am I going to do with my life? Personal and collective identities as motivators of action. Educational Psychologist, 44(2), 78-89. https://doi.org/10.1080/00461520902832368

Ekici, G. (2014). Views of teachers on responsibility perceptions about students' academic achievement and failure: The case of pre-service teachers of biology. Ilkögrretim Online, 13(4), 1414-1448.

Field, A. (2009). Discovering statistic using SPSS for Windows. London: SAGE Publications.

Gallardo-Echenique, E. E., Marqués-Molías, L., Bullen, M., \& Strijbos, J. M. (2015). Let's talk about digital learners in the digital era. The International Review of Research in Open and Distributed Learning, 16(3), 1-13. https://doi.org/10.19173/irrodl.v16i3.2196

Gerlich, R. N., Browning, L., \& Westermann, L. (2010). The social media affinity scale: Implications for education. Contemporary Issues in Education Research, 3(11), 35-42. https://doi.org/10.19030/cier.v3i11.245

Greenhow, C., Robelia, B., \& Hughes, J. E. (2009). Web 2.0 and classroom research: What path should we take now? Educational Researcher, 38(4), 246-259. https://doi.org/10.3102/ 0013189X09336671 


\section{MInstitute Macrothink}

Gündoğdu, K., Silman, F., \& Ozan, C. (2011). A comparative study on perception of teachers on the use of computers in elementary schools of Turkey and T.R.N.C. International Online Journal of Educational Sciences, 3(1), 113-137.

Haesler, D. (2012). High expectations and student success prepared for Springfield R-XII Public Schools. Retrieved September 12, 2017, from https://danhaesler.com/wp-content/ uploads/2015/02/High-Expectations-Mindset.pdf

Hale, W. D., Fiedler, L. R., \& Cochran, C. D. (1992). The revised generalized expectancy for success scale: A validity and reliability study. Journal of Clinical Psychology, 48(4), 517-521. https://doi.org/10.1002/1097-4679(199207)48:4\%3C517::AID-JCLP2270480413\%3E3.0.CO ;2-Z

Hu, S., Gu, J., \& Zhang, S. (2017). Social media usage, self-efficacy and cultural intelligence: A longitudinal empirical research in China (pp. 261-271). The Sixteenth Wuhan International Conference on E-Business-Social Media in the Workplace.

Jacobsen, W. C., \& Forste, R. (2011). The wired generation: Academic and social outcomes of electronic media use among university students. Cyberpsychology, Behavior, and Social Networking, 14(5), 275-280. https://doi.org/10.1089/cyber.2010.0135

Jenkins-Guarnieri, M. A., Wright, S. L., \& Johnson, B. (2013). Development and validation of a social media use integration scale. Psychology of Popular Media Culture, 2(1), 38-50. https://doi.org/10.1037/a0030277

Jöreskog, K. G., \& Sorbom, D. (1996). LISREL 8 reference guide. Lincolnwood, IL: Scientific Software International.

Kalaycı, Ş. (2010). SPSS uygulamalı çok değişkenli istatistik teknikleri. Ankara: Asil Yayın Dağıtım.

Kaplan, A. M., \& Haenlein, M. (2010). Users of the world, unite! The challenges and opportunities of social media. Business Horizons, 53(1), 59-68. https://doi.org/10.1016/ j.bushor.2009.09.003

Kelly, T., Thompson, S., Green, B., \& Vice, J. (2017). Facebook faculty and tweeting teachers: Social media as a learning, development, and support mechanism for pre-service, in-service, and post-service educators. In P. Resta \& S. Smith (Eds.), Proceedings of Society for Information Technology \& Teacher Education International Conference (pp. 1655-1659). Austin, TX, United States: Association for the Advancement of Computing in Education (AACE).

Kirschner, P. A., \& Kapinski, A. C . (2010). Facebook and academic performance. Computers in Human Behavior, 26, 1237-1245. https://doi.org/10.1016/j.chb.2010.03.024

Kline, P. (1994). An easy guide to factor analysis. Abingdon-on-Thames: Routledge.

Kline, R. B. (2005). Principles and practice of structural equation modeling (2nd ed.). NY: Guilford Publications, Inc. 


\section{Macrothink}

Krämer, N. C., Karacora, B., Lucas, G., Dehghani, M., Rüther, G., \& Gratch, J. (2016). Closing the gender gap in STEM with friendly male instructors? On the effects of rapport behavior and gender of a virtual agent in an instructional interaction. Computers \& Education, 99, 1-13. https://doi.org/10.1016/j.compedu.2016.04.002

Krutka, D. G., Nowell, S., \& McMahon-Whitlock, A. (2017). Towards a social media pedagogy: successes and shortcomings in educative uses of Twitter with teacher candidates (Abstract). Journal of Technology and Teacher Education, 25(2), 215-240.

Lau, W. W. F. (2017). Effects of social media usage and social media multitasking on the academic performance of university students. Computers in Human Behavior, 68, 286-291. https://doi.org/10.1016/j.chb.2016.11.043

Legaree, B. A. (2015). Considering the changing face of social media in higher education. FEMS Microbiology Letters, 362(16), 1-3. https://doi.org/10.1093/femsle/fnv128

Lenhart, A. (2015). Teens, social media \& technology overview 2015: Smartphones facilitate shifts in communication landscape for teens. Washington: Pew Internet \& American Life Project.

Lenhart, A., Purcell, K., Smith, A., \& Zickuhr, K. (2010). Social media and mobile internet use among teens and youngs adults. Washington: Pew Internet \& American Life Project.

Levine, L. E., Waite, B. M., \& Bowman, L. L. (2007). Electronic media use, reading, and academic distractibility in college youth. Cyberpsychology \& Behavior, 10(4), 561-566. https://doi.org/10.1089/cpb.2007.9990

Lynn, P., Erens, B., \& Sturgis, P. (2012). A strategy for survey methods research in the UK. ESRC Survey Resources Network. Retrieved August 28, 2017, from http://surveynet.ac.uk/ srn/Vision\%20for \%20Survey\%20Methods.pdf

Manca, S., \& Ranieri, M. (2016). Yes for sharing, no for teaching!: Social Media in academic practices. Internet and Higher Education, 29, 63-74. https://doi.org/10.1016/j.iheduc.2015. 12.004

Mather, C., Douglas, T., \& O'Brien, J. (2017). Identifying opportunities to integrate digital professionalism into curriculum: A comparison of social media use by health profession students at an Australian University in 2013 and 2016. Informatics, 4(2), 1-14. https://doi.org/10.3390/informatics4020010

Matzat, U., \& Vrieling, E. M. (2016). Self-regulated learning and social media-A 'natural alliance'? Evidence on students' self-regulation of learning, social media use, and student-teacher relationship. Learning, Media and Technology, 41(1), 73-99. https://doi.org/ 10.1080/17439884.2015.1064953

McLean, L., \& Griffiths, M. (2013). The psychological effects of videogames on young people: A review. Revista de Psicologia, Ciències de l'Educació i de l'Esport, 31, 119-133.

McLoughlin, C., \& Lee, M. J. (2008). The three p's of pedagogy for the networked society: 


\section{$\Lambda$ Macrothink}

Personalization, participation, and productivity. International Journal of Teaching and Learning in Higher Education, 20(1), 10-27.

McLoughlin, C., \& Lee, M. J. V. (2007). Social software and participatory learning: Pedagogical choices with technology affordances in the Web 2.0 era. Proceedings ascilite Singapore, 664-675. Retrieved August 28, 2017, from http://www.dlc-ubc.ca/dlc3/educ500/ wp-content/uploads/sites/24/2011/07/mcloughlin.pdf

Mega, C., Ronconi, L., \& Beni, R. D. (2014). What makes a good student? how emotions, self-regulated learning, and motivation contribute to academic achievement. Journal of Educational Psychology, 106(1), 121-131. https://doi.org/10.1037/a0033546

Mingle, J., \& Adams, M. (2015). Social media network participation and academic performance in senior high schools in Ghana. Library Philosophy and Practice, 1-51.

Nilsen, A. G., \& Almås, A. G. (2016). Added values and challenges social media represent in the hybridisation of teacher training. European Journal of Open, Distance and E-Learning, 19(2), 75-87.

Nurmi, J. E., Aunola, K., Salmela-Aro, K., \& Lindroos, M. (2003). The role of success expectation and task-avoidance in academic performance and satisfaction: Three studies on antecedents, consequences and correlates. Contemporary Educational Psychology, 28(1), 59-90. https://doi.org/10.1016/S0361-476X(02)00014-0

O’Reilly, T., \& Battelle, J. (2009). Web squared: Web 2.0 five years on. Retrieved August 28, 2017, from http://www.cs.cmu.edu/ jhm/Readings/web2009_websquared-whitepaper.pdf

Ozan, C. (2009). İlköğretim sınıf öğretmenlerinin eğitim teknolojileri açısından yeterlilikleri (Erzurum ili örneği) (Unpublished master thesis, Atatürk University, Erzurum).

Ozan, C., \& Taşgın, A. (2017). Analysis of prospective teachers' sellf-efficacy towards educational technology standards. Educational Technology Theory and Practice, 7(2), 236-253. https://doi.org/10.17943/etku.307575

Özsarı, İ., \& Batdal Karaduman, G. (2016). Investigation of education faculty students' social media usage and loneliness. Journal of Research in Education and Teaching, 5(41), 380-389.

Öztürk, M., \& Akgün, Ö. E. (2012). Unıversity students' purposes in using social networking sites, and their opinions on using these sites in education. Sakarya University Journal of Education, 2(3), 49-67.

Paliszkiewicz, J., Sawicka, M. M., Filipiak, T., Svanadze, S., \& Jikia, M. (2017). Time-spent online as a factor in usage and awareness of drawbacks in social media. Issues in Information Systems, 18(4), 135-145.

Pittman, M. (2015). Creating, consuming, and connection: Examining the relationship between social media engagement and loneliness. The Journal of Social Media \& Society 4(1), 66-99.

Prensky, M. (2001). Digital natives, digital immigrants. On the Horizon, 9(5), 1-6. 
https://doi.org/10.1108/10748120110424816

Quinn, K. (2016). Why we share: A uses and gratifications approach to privacy regulation in social media use. Journal of Broadcasting \& Electronic Media, 60(1), 61-86. https://doi.org/ 10.1080/08838151.2015.1127245

Ravizza, S. M., Hambrick, D. Z., \& Fenn, K. M. (2014). Non-academic internet use in the classroom is negatively related to classroom learning regardless of intellectual ability. Computers \& Education, 78, 109-114. https://doi.org/10.1016/j.compedu.2014.05.007

Reese, G., \& Dietrich, J. (2014). I am therefore I do: Group 1dentification and effort for the achievement goals. Social Sciences, 3(4), 941-947. https://doi.org/10.3390/socsci3040941

Reyes, M. R., Brackett, M. A., Rivers, S. E., White, M., \& Salovey, P. (2012). Classroom emotional climate, student engagement, and academic achievement. Journal of Educational Psychology, 104(3), 1-14. https://doi.org/10.1037/a0027268

Rhodus, T., Buchem, V. V., \& Witney, B. (2007). Web 2.0: Building online communities using social networking Technologies. Retrieved April 15, 2017, from https://webgarden.osu.edu/ buckeye2007.pdf

Rivkin, S. V., Hanushek, E. A., \& Kain, J. F. (2005). Teachers, schools, and academic achievement Econometrica, 73(2), 417-458. https://doi.org/10.1111/j.1468-0262.2005. 00584.x

Sarsar, F., Başbay, M., \& Başbay, A. (2016). Use of social media in learning and teaching process. Mersin Üniversitesi Eğitim Fakültesi Dergisi, 11(2), 418-431. https://doi.org/ 10.17860/efd.98783

Şimşek, Ö. F. (2007). Yapısal eşitlik modellemesine giriş: Temel illkeler ve LISREL uygulamaları. Ankara: Ekinoks Yayıncılık.

Solmaz, B., Tekin, G., Herzem, Z., \& Demir, M. (2013). An application on the use of internet and social media. Selçuk Üniversitesi İletişim Fakültesi Akademik Dergisi, 7(4), 23-32.

Tabachnick, B. G., \& Fidell, L. S. (2007). Using multivariate statistics (5th ed.). Boston, MA: Pearson Education, Inc./Allyn and Bacon.

Tella, A. (2007). The impact of motivation on student's academic achievement and learning outcomes in mathematics among secondary school students in Nigeria. Eurasia Journal of Mathematics, Science \& Technology Education, 3(2), 149-156. https://doi.org/10.12973/ ejmste/75390

Villanti, A. C., Johnson, A. L., Ilakkuvan, V., Jacobs, M. A., Graham, A. L., \& Rath, J. M. (2017). Social media use and access to digital technology in US young adults in 2016. Journal of Medical Internet Research, 19(6), 2-14. https://doi.org/10.2196/jmir.7303

Wasserman, I. M., \& Richmond-Abbott, M. (2005). Gender and the Internet: Causes of variation in access, level, and scope of use. Social Science Quarterly, 86, 252-270. https://doi.org/10.1111/j.0038-4941.2005.00301.x 


\section{Macrothink}

Wentzel, K. R., \& Wigfield, A. (1998). Academic and social motivational influences on students' academic performance. Educational Psychology Review, 10(2), 155-175. https://doi.org/10.1023/A:1022137619834

Whiting, A., \& Williams, D. (2013). Why people use social media: A uses and gratifications approach, Qualitative Market Research: An International Journal, 16(4), 362-369. https://doi.org/10.1108/QMR-06-2013-0041

Wigfield, A. (1994). Expectancy-value theory of achievement motivation: A developmental perspective. Educational Psychology Review, 6(1), 49-78. https://doi.org/10.1007/BF0220 9024

Zhan, L., Sun, Y., Wang, N., \& Zhang, X. (2016). Understanding the influence of social media on people's life satisfaction through two competing explanatory mechanisms. Aslib Journal of Information Management, 68(3), 347-361. https://doi.org/10.1108/AJIM-122015-0195

\section{Copyright Disclaimer}

Copyright for this article is retained by the author(s), with first publication rights granted to the journal.

This is an open-access article distributed under the terms and conditions of the Creative Commons Attribution license (http://creativecommons.org/licenses/by/3.0/). 